\title{
References
}

1. Barsova, Y. (1987). Essays on the history of musical notation (XVI - the first half of the XVII century). Moscow: Moscow State Conservatory [in Russian].

2. Berehova, O. M. (2006). Communication in the social and cultural space of Ukraine: technology and creativity? Sciences issue. Kyiv: NMAU im. P. I. Chaikovskoho [in Ukrainian].

3. Bonfeld, M. Sh. (2007). The semantics of musical speech. Music as a form of intellectual activity. Moscow: KomKnyha, pp. 82-141 [in Russian].

4. Herasymova-Persydskaia, N. A. (1986). The historical condition of musical perception and the typology of culture. Musical perception as a subject of complex research: coll. of articles. Kyiv: Muz. Ukraina, pp. 18-28 [in Russian].

5. Hetman, Y. M. (1991). Thesaurus as an instrument of modern linguistics: (on the material of Russian studies). Extended abstract of Doctor's thesis Kyiv [in Ukrainian].

6. Holovynskyi, H. (1981). Composer and folklore: from the experience of masters of the XIX-XX centuries: essays. Moscow: Muzika [in Russian].

7. Zakharova, O. Y. (1983). Rhetoric and Western European music of the 17th - first half of the 17th century: principles, techniques. Moscow: Muzika [in Russian].

8. Zeifas, N. (1981). Matteson and Orchestration Theory. History and Modernity: coll. of articles. Leningrad: Sov. kompozytor, pp. 33-55 [in Russian]. Russian].

9. История полифонии: в 7 issue - issue 2 A: Renaissance music: 15th century. (1989). Moscow: Muzika [in

10. Kalashnyk, M. P. (2010). Musical composer thesaurus: Aspects of vivchennya: monograph. Kyiv; Kharkiv: SPDFO Mosiakyn V. M. [in Ukrainian].

11. Konen, V. (1968 Theater and symphony. Moscow: Muzika [in Russian].

12. Subota, A. V. (2007). Analysis of factors determining the status of a musical instrument in culture, using the example of a Russian seven-string guitar. Education, culture and art in the age of civilization globalization: Proceedings of the International Scientific and Practical Conference, (pp. 167-169). Kharkov: KhDAK [in Russian].

13. Tsuranova, O. A. (2009). S. V. Smolenskyi and a New direction in Russian sacred music of the late XIX early XX centuries: Candidate's thesis. Kharkov [in Russian].

Стаття надійшла до редакції 21.05.2019 p.

Удк 7.012.185+74.01

Прищенко Світлана Валеріївна.

доктор наук габіліт. у галузі дизайну, професор кафедри дизайну середовища

Національної академії керівних кадрів культури і мистецтв,

член Спілки дизайнерів України

ORCID 0000-0003-3482-6858

akademiki@ukr.net

\section{ФУНКЦИОНАЛІЗМ БАУХАУЗУ ТА ЙОГО ВПЛИВ НА РОЗВИТОК ДИЗАЙНУ І РЕКЛАМИ (ДО 100-річного ювілею)}

Мета статті - теоретично узагальнити вагомий вплив Вищої школи архітектури та дизайну «Баухауз» (1919-2019), культурного символу Німеччини на становлення і розвиток художньо-проектної діяльності XX - початку XXI ст. Методологія дослідження полягає в міждисциплінарному підході до фрормоутворення об'єктів дизайну, застосовуючи системно-структурний, соціокультурний, аксіологічний, історико-мистецтвознавчий та компаративний методи. Наукова новизна. Комплексно розглянуто культурно-естетичні засади функціонального стилю в предметно-просторовому та візуально-інформаційному середовищі: меблях, посуді, текстилі, знакових фрормах, промисловій і рекламній графіці, фотографріці, плакаті, упаковці, дизайні книги, web-дизайні. На підставі проведеного стилістичного аналізу емпіричних матеріалів різних країн доведено, що стилістика школи «Баухауз» має художню та функціональну цінності, а її твори набули статусу світової мистецької спадщини. Висновки. В умовах сучасного стильового хаосу, трансформацій постмодернізму в пост-постмодернізм, товарного перенасичення і гіперспоживання все більшої популярності набуває функціоналізм у різновидах дизайну та реклами.

Ключові слова: візуальний дискурс, дизайн, стиль, функціоналізм, естетика, рекламна графріка, плакат, візуальні комунікації.

Прищенко Светлана Валерьевна, доктор наук хабилит. в сфрере дизайна, профрессор кафредры дизайна среды Национальной академии руководящих кадров культуры и искусств

Функционализм Баухауса и его влияние на развитие дизайна и рекламы

Цель статьи - теоретически обобщить значительное влияние Высшей школы архитектуры и дизайна «Баухауз» (1919-2019), культурного символа Германии на становление и развитие художественно-проектной деятельности XX - начала XXI ст. Методология исследования состоит в междисциплинарном подходе к фрормообразованию объектов дизайна, используя системно-структурный, социокультурный, аксиологический, историко-

(ㄱ) Прищенко С. В., 2019 
искусствоведческий и компаративный методы. Научная новизна. Комплексно рассмотрены культурноэстетические основы функционального стиля в предметно-пространственной и визуально-информационной среде: мебели, посуде, текстиле, знаковых фрормах, промышленной и рекламной графике, фотографрике, плакате, упаковке, дизайне книги, web-дизайне. На основании проведеного стилистического анализа эмпирических материалов разных стран доказано, что стилистика школы «Баухаус» имеет художественную и функциональную ценности, а её произведения получили статус мирового художественного наследия. Выводы. В условиях современного стилевого хаоса, трансформаций постмодернизма в пост-постмодернизм и товарного перенасыщения все более популярным становится функционализм в разновидностях дизайна и рекламы.

Ключевые слова: визуальный дискурс, дизайн, стиль, функционализм, эстетика, рекламная графика, плакат, визуальные коммуникации.

Pryshchenko Svitlana, Doctor habil. in Design, Professor of Department Environment Design in the National Academy of Managerial staff in Culture and Arts

Bauhaus' Functionalism and its impact on the development of Design and Advertising

The purpose of the article is to theoretical summarize the significant influence of the Bauhaus higher school of Architecture and Design (1919-2019), the cultural symbol of Germany on the formation and development of art-project activities of the 20th - beginning of the 21st cent. The methodology consists in the interdisciplinary approach to forming the design objects, using system-structural, socio-cultural, axiological, art-historical and comparative methods. Scientific Novelty. The culture-aesthetic fundamentals of functional style in the subject-spatial and visual-informational areas are comprehensively considered: the furniture, utensils, textiles, sign forms, industrial and advertising graphics, photographics, poster, packaging, book design, web-design also. Based on the stylistic analysis of empirical materials from different countries, it is proved that the style of the Bauhaus school has artistic and functional values, and its works have received the status of world artistic heritage. Conclusions. In the conditions of contemporary stylistic chaos, the transformation of Postmodernism into Post-postmodernism and production glut, Functionalism are becoming increasingly popular in the varieties of Design and Advertising. The study made it possible to conclude that along with the postmodern and post-postmodern tendencies, the fundamental foundations and principles of Bauhaus compositional formation continue to live. At the beginning of the XXI century. in terms of style chaos, functionalism, constructivism, minimalism, sometimes combining with elements of other styles, forming modern polystyles, are quite popular in the varieties of design and advertising. Analyzing the components of the art and design culture, paying special attention to its aesthetic problems, we emphasize, firstly, Bauhaus has significantly influenced the design and advertising in the context of visual communications, and secondly, the formation of design objects is determined by the target groups based on target groups certain functions and aesthetic ideals. The processes of globalization and deglobalization have led to contradictory situations in the cultural and artistic environment, characterized not only by diffuse enrichment, eclecticism, kitsch, pseudonationalization, but also by the return to the "world of pure forms" of the Bauhaus - flatness, geometry, search of color graphs.

Key words: visual discourse, design, style, functionalism, aesthetics, advertising graphics, poster, visual communications.

Актуальність теми. 2019 року Баухауз - Вища школа архітектури та дизайну, основоположний вплив якої на дизайн і рекламу XX - початку XXI ст. складно переоцініти, - відзначала 100-річний ювілей. Протягом 2019 р. відбулася велика кількість ретроспективних виставок з цього приводу, тематичних турів, семінарів і воркшопів по всій Німеччині, але найбільша кількість їх була в Берліні, Веймарі, Дессау, Лейпцигу та Мюнхені. Надруковано неймовірну кількість книг, альбомів і буклетів, присвячених мистецькій спадщині Баухаузу: архітектурі, живописним пошукам, дизайну середовища, одягу, промисловим виробам, рекламній графріці, упаковці, дизайну книги і періодичних видань. Вітрини багатьох магазинів меблів, освітлення, текстилю, посуду, одягу, канцтоварів, іграшок були оформлені в стилістиці Баухаузу щодо форм, кольорів, матеріалів [21].

Аналіз останніх досліджень. Історію Баухаузу на сьогодні досліджено достатньо повно, зокрема представленими в бібліографічному списку публікаціями [1; 4; 7-19], однак, не розкритими повною мірою залишаються стилістичні аспекти функціоналізму в рамках сучасних інтерпретацій, зокрема в Україні. Деякі дослідники часто зводять цінність Баухаузу лише до утилітарних аспектів, проте кращі об'єкти його мистецької спадщини мають цінність саме тому, що художники не відокремлювали естетику та корисність, зберігали єдність мистецтва і технологій, взяли на себе відповідальність за революційні принципи дизайну та створили системну форму проектування, порівняно з канонічним типом діяльності.

Мета статті - теоретично узагальнити вагомий вплив творчих концепцій Баухаузу на становлення і розвиток художньо-проектної діяльності XX - початку XXI ст.

Виклад основного матеріалу. Баухауз - художньо-технічний навчальний заклад Німеччини, перша в історії суто дизайнерська школа з принципово новими програмами і формами навчання, науковою та проектною діяльністю, інтернаціональним складом викладачів і студентів, яку було засновано архітектором В.Гропіусом 1919 р. у Веймарі, потім 1925 р. переміщену до Дессау, 1930 р. - до Берліну і закриту 1933 р. нацистами.

Баухауз став носієм ідей функціоналізму і зробив вагомий внесок у розвиток світового дизайну - художньо-проектної культури. Баухауз формував дизайн-мислення, орієнтоване на споживача, вважав за мету не приваблення покупців, а намагався зробити революцію у співвідношеннях «форма функція - нові матеріали». Його девізом став вислів «форма йде за функцією». В результаті закриття Баухаузу видатні викладачі Вальтер Гропіус, Ласло Могой-Надь, Джозеф Алберс, Міс ван дер Рое емігрували 
до США. Там їхня творча діяльність сприяла розвитку дизайну в загальносвітовому масштабі. Серед інших викладачів зазначимо Анрі ван де Вельде, Ліонеля Фейнінгера, Йоханеса Іттена, Оскара Шлеммера, Пауля Клеє, Василя Кандинського, Тео ван Дусбурга. Методика викладання фахових дисциплін визначила підготовку архітекторів і дизайнерів не лише у XX ст., вони донині помітно впливають на архітектурну та дизайн-освіту. Баухауз мав транснаціональний ефект, вважається «фабрикою талантів сучасної епохи» та продовжує впливати на мистецькі практики, архітектуру, дизайн і рекламу по всьому світу [3, 358-359].

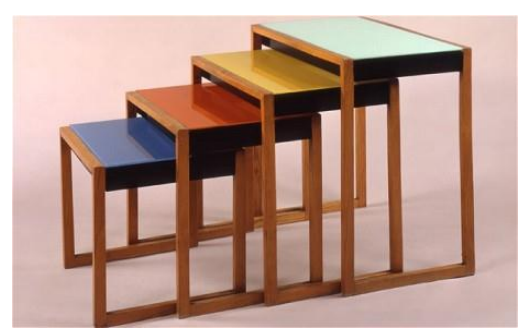

a)

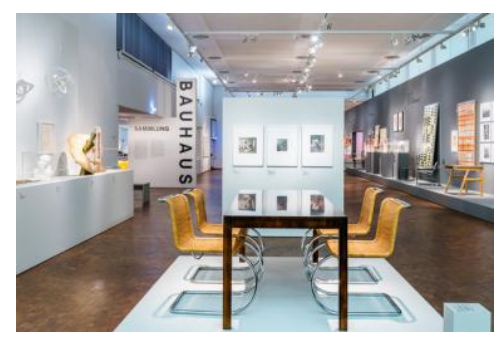

б)

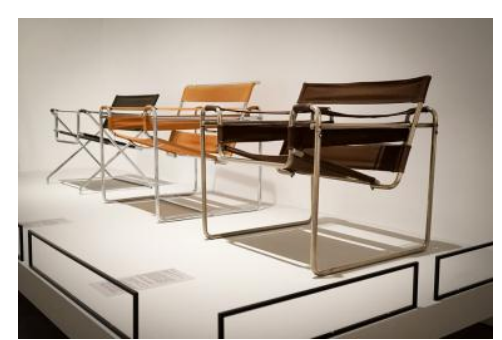

8)

\section{Мал. 1. а) Джозеф Алберс. Комплект стільців, 1927; б) Музей дизайну «Баухауз-архів». Берлін, 2015; в) Марсель Брейєр. Крісло, 1925. Фото з сайту www.bauhaus.de}

Дослідниця Оксана Чепелик нагадує, що за часів, коли індустріальне суспільство перебувало в кризовому стані, лише Баухауз переймався питанням, як процес модернізації міг би бути освоєний за допомогою дизайну. Викладачі і студенти прагнули знищити прірву між мистецтвом та виробництвом, повертаючись до ремесла як бази всієї художньої діяльності і розробляючи об'єкти та просторові вирішення, які повинні були сформувати основу більш гуманного майбутнього суспільства. Головним принципом була нова єдність мистецтва і технологій, саме тому Баухауз став «іконою модернізму» [5, 371].

1920-ті рр. були надзвичайно творчим десятиліттям, з абсолютно новаторською та функціональною «візуальною мовою» (термін введений Гропіусом). Кубізм, конструктивізм, футуризм і дадаїзм мали колосальний вплив на принципи візуалізації: асиметричні композиції, контрастні кольори, графічні прийоми. Функціоналізм був соціально-естетичним рухом в архітектурі та прикладних мистецтвах, отримав великого поширення в Європі та Америці у всіх видах дизайну та реклами і став домінувати 3 середини XX ст. - це антіеклектика, максимальне врахування потреб людини, максимальні зручність та комфорт (ергономіка), екологічність, інтернаціональна стилістика: геометричні форми, площинні насичені кольори, найчастіше повна відсутність декору і національної ідентичності. Також дизайнери відмовилися від національних шрифтів, наприклад, від німецької «фрактури», національних ознак та намагалися створити наднаціональний стиль. Дизайн став розумітися не лише як сфера проектування, а й як вид творчої діяльності, як концепція, як нова мистецька парадигма, як соціокультурний процес, а стиль - як ідеологія фрорми і прояв візуальної культури.

Тексти, фотографії і графічні елементи були єдиним цілім, яке подавалося покупцям у вигляді чіткого та зрозумілого звернення. Комбінація типографіки та фотографріки, започаткована Л.МогойНадєм 1923 р., висунула концепцію функціональної графіки, реклама була визнана необхідним завданням тогочасного суспільства, її фрнкція ретельно вивчена, а її дизайн став візуально організованим [14]. Й.Шмідт представив студентам систематичне навчання дизайну шрифтів та рекламної графіки, яке він також розповсюдив на виставковий дизайн. Це призвело до пошуків експериментальних форм в архітектурі, скульптурі та фотографії, які повинні були сформувати образ Баухаузу на пересувних виставках. Багато експериментували мистці і в техніці колажу, активно використовуючи такий підхід у графічному дизайні та рекламі.

Олександр Родченко у своїй різноплановій творчості зазнав впливів Корбюзьє, Могой-Надя, Пікассо, Мондріана, Ман Рея. Перша зустріч Родченка з Баухаузом відбулася 1927 року - це була невеличка фотовиставка його робіт. Згодом його знімки набули визнання в країнах Західної Європи як оригінальні за композицією та ракурсами. Приміром, 1929 р. Родченко готувався одразу до виставок у Цюріху, Нью-Йорку, Антверпені, Чикаго, Токіо. Проблемами нової візуальної культури діячі Баухаузу вже опікувалися на початку 20-х рр. XX ст. і Родченку було запропоновано виступити з приводу терміна «конструктивізм», який набув великої популярності серед художників й архітекторів, проте ще недостатньо ясний та зрозумілий [2, 77-78].

Ідеальна геометрія та функціональність - саме завдяки своїй раціональності, простоті й легкості стиль Баухаус став відомим в усьому світі. Творче об'єднання революційно мислячих архітекторів, директори школи виступали проти приватної розкоші й наголошували на соціальній фрункції дизайну. На їхню думку, архітектура після Першої Світової війни мала стати кардинально іншою - з орієнтиром на технології масового виробництва. «Кожен предмет має до кінця відповідати своєму призначенню, тобто виконувати всі практичні фрукції, бути зручним, дешевим і красивим», - так своє бачення сучасної архітектури пояснював головний натхненник В.Гропіус. 1933 р. уряд вирішив, що політика Баухаузу 
суперечить державній ідеології. Попередньо школа не раз зазнавала утисків від нацистів: Баухауз відверто називали «розсадником» комунізму. І це попри те, що саме представники цієї течії розробили майже всю символіку для Націонал-соціалістичної робітничої партії Німеччини. Хоча школу закрили, її вчителі та учні продовжували поширювати свої ідеї за кордоном. Так, останній директор Баухаузу Людвіг Міс ван дер Рое здобув славу в США, де його прозвали батьком інтернаціонального стилю. Як виклик помпезній класиці доби Гітлера, М.Рое розбудовував світ під гаслом «менше значить більше». Його будинок для сім'ї Франсуорт, кампус Іллінойського технологічного інституту та численні хмарочоси в Чикаго вражають простотою і гармонійним поєднанням скла та сталі [1].

Інший відомий австрійський дизайнер Герберт Байєр вчився, а згодом викладав у Баухаузі, плідно працював у графіці, живопису, фотографії, рекламі. В 1928-1938 рр. був художнім керівником Берлінської рекламної агенції «Studio Dorland». 31938 р. в американській еміграції Г.Байєр працював художником реклами, графічним дизайнером, дизайнером виставок, консультантом з мистецтва та дизайну. Найбільш цікавими були виставки в США під його кураторством: «Баухауз 1919-1928» (1938), «Сучасне мистецтво в рекламі» (1945), «50 років Баухаузу» (1968), а плакати його авторства демонструють відповідні кращі стилістичні традиції: насичені площинні кольори, асиметрію, ритм геометричних фрігур, кубістичні знахідки.

Дизайн і рекламна графіка другої половини XX ст. запозичили модульні сітки, геометризм, монтаж елементів, обмежену колірну палітру, в який домінували три основні ахроматичні (білий, сірий, чорний) та три основні хроматичні кольори (жовтий, синій, червоний) з використанням трьох основних фігур (квадрата, трикутника, круга). Культурно-естетичні засади функціоналізму Баухаузу поступово поширювалися світом: колишні учні відкривали школи та студії, просуваючи головну ідею «від ремесла до індустріального виробництва» у промисловому та графічному дизайні, дизайні архітектурного середовища, як наприклад, в Ульмській школі дизайну в Німеччині, засновану 1953 р. випускником Баухаузу Максом Біллом, відомим швейцарським художником, архітектором і дизайнером.

Протягом XX ст. в Україні функціональний стиль мав найбільш відчутні втілення в різновидах дизайну та реклами промислових східних регіонів Харківщини, Донбасу, Дніпропетровщини, Запоріжжя. Не заглиблюючись у суто конструктивні й технологічні аспекти проектування, відзначимо в цілому актуальність фрунцціонального стилю в сучасному предметно-просторовому та візуальноінформаційному середовищі. На початку XXI ст. відбулися суттєві зміни уявлень про дизайн і рекламу у зв'язку із процесами глобалізації та одночасної етнокультурної ідентифікації, гіперспоживанням і паралельним зниженням загальнокультурного рівня суспільства, значним розширенням комунікативного простору за рахунок Інтернету. Відбулися й суттєві соціальні зміни, оскільки розвиток технологій спричинив появу ідей гуманістичного універсального дизайну - «товари для всіх і кожного», а реклама грає в цьому вагому роль, просуваючи товари на масовому ринку. Функціональний стиль у web-дизайні нині $\epsilon$ найпоширенішим, графічна система якого забезпечуються такими фрормотворчими чинниками: прямокутно-композиційною структурою web-сторінки, однорідними геометричними елементами, насиченими колірними сполученнями [3].

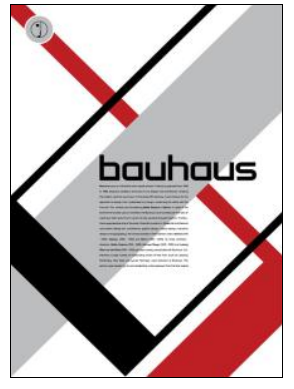

a)

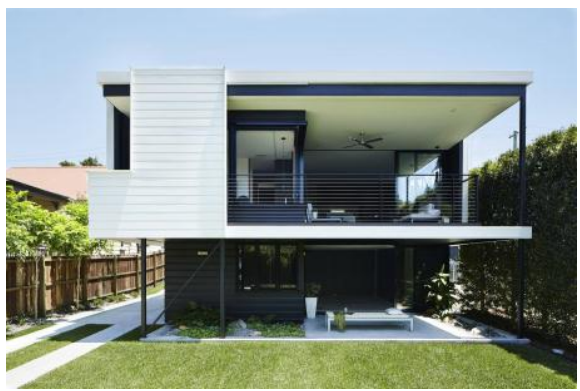

б)

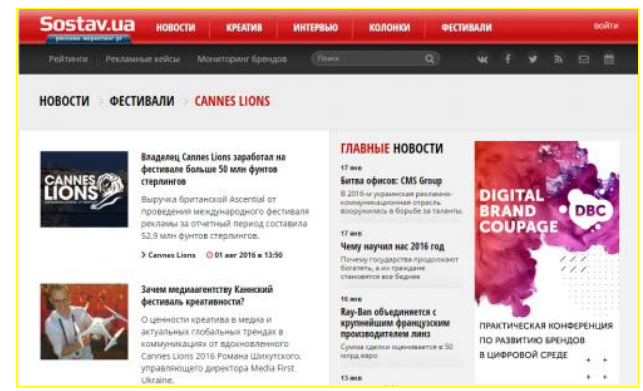

в)

\section{Мал. 2. а) плакат ретроспективної виставки Баухаузу, 2011; б) приватний будинок у Брисбені. Австралія, 2014; в) функціональний стиль y web-дизайні, 2017. Головна сторінка порталу про рекламу www.sostav.ua}

В умовах соціокультурної динаміки можна спостерігати деяку «розмитість» стильових напрямів або взагалі їхню відсутність, що узагальнено визначається терміном «постмодернізм» як наявність характерного еклектизму в постіндустріальному суспільстві та розмаїття художніх пошуків другої половини $X X$ - початку XXI ст. Це явище виникло як ідея переосмислення культурної перенасиченості в європейському суспільстві, де зростала кількість інформації, втрачалися звичні орієнтири, виникала потреба у співвіднесенні традиційних і нових цінностей. На першому етапі постмодернізм відрізнявся великою кількістю теоретичних, часто суперечливих положень, використовувався у сфері художньої культури, згодом отримав більш-менш однорідне тлумачення, почав характеризувати певні тенденції у філософії, науці, релігії, політиці, рекламі, способі життя і в цілому періодизацію культури, відображати співі- 
снування різноманітних стилів у мистецтві, архітектурі та дизайні, отримавши узагальнену назву «складний культурний бульйон». Отже, постмодернізм став типом світогляду, став більшим, ніж стиль, скоріше, певним історичним періодом у розвитку культури загалом.

Постмодернізм має власні типологічні ознаки: використання будь-яких готових фрорм від художніх до утилітарних, поширення фотографії і комп'ютерних спецефектів, свідоме порушення співрозмірних величин зображальних елементів, запозичення ідей з інших видів мистецтва, рімейк, інтерпретація, комбінація, фррагментарність, епатаж, інсталяція, колажність та тиражування [9, 447-448]. Нині рамки постмодернізму розширено, формуються нові стилістичні тенденції в архітектурі, мистецтві, дизайні та рекламі за рахунок образно-асоціативного підходу у використанні елементів, поширюються метафоричність, амбівалентність, візуальні парадокси, іронія, надання старим формам нового контексту, сутність колірної гармонії ускладнюється, збільшується різноманіття жанрів, переосмислюються художні традиції, не заперечуються співіснування різних культурних систем і діалог культур. Сучасна свідома еклектика набуває самостійної художньої цінності, однак, можна назвати лише окремі приклади вдалих трансформацій або експериментів. Пост-постмодерністській світ завжди є споживчим, оскільки породжує спрощені варіанти соціальності, спрощені ідеї, спрощене мистецтво, та, як наслідок, породжує спрощену і тиражовану «красу» для масового споживання, яка має надлишкові візуальні засоби для привертання уваги.

Пост-постмодернізм (або «метамодернізм») став реакцією на постглобалізацію та невідповідність постмодерністських рис вимогам сучасного інформаційного суспільства. На нашу думку, метамодерн може бути визнаним новим етапом лише хронологічно, оскільки термін з'явився 2010 р. та ще не має принципово нових рис, але в багатьох галузях відбуваються певні зміни. В нових соціокультурних умовах одночасно співіснують дві тенденції: глобальний інформаційний простір та регіональний культурний простір, тому доцільніше вважати метамодернізм перехідним етапом, оскільки здебільшого він зберігає всі ознаки постмодернізму. Цей термін був запропонований молодими фрілософами 3 Нідерландів Р.Аккером і Т.Вермюленом, які спробували конкретизувати сучасну культурну реальність, оскільки вони вважають, що глобалізація не зробила світ єдиним, а інформаційні технології хоча й допомагають спілкуванню без кордонів, однак поляризують суспільство за інформаційною ознакою - доступом до неї та володінням нею. Метамодернізм намагається знову знайти смисл культури і мистецтва, випробовує різні підходи, шукає істину, яка поза межами його досягнення та яку він не очікує знайти. Глибина творів інша, ніж у постмодерні - вона долає «рамки», вона багатовимірна і невловима, вона виправдовує непостійність та дуальність людини, глядачу не пропонують готових концепцій, а спонукають знайти самому. Це є принципом індивідуальності, духовним аристократизмом і творчою мораллю [6].

Дизайн-продукція епохи пост-постмодерну створюється поки що з використанням усіх стилістичних принципів постмодернізму, однак, візуальними трендами 2017-2019 рр. були мінімалістичний і функціональний стилі, кольори стають більш насиченими, елементи - площинними, площина або простір - модульними; чітко вираженими є комп'ютерні спецефекти або ручна графріка; а художньокомпозиційні принципи функціоналізму залишаються основними творчими підходами [3].
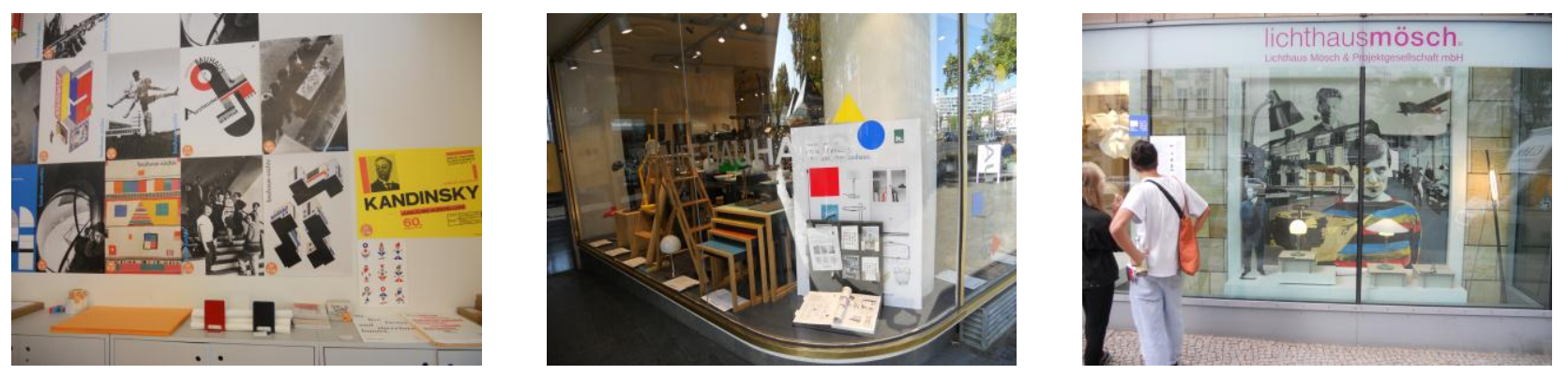

Мал. 3. Баухаузу - 100 років. Берлін, 2019. Фото авторки

Наукова новизна. Вперше в українському мистецтвознавстві комплексно розглянуто культурноестетичні засади функціонального стилю в предметно-просторовому та візуально-інформаційному середовищі: меблях, посуді, текстилі, знакових фрормах, промисловій і рекламній графіці, фотографіці, плакаті, упаковці, дизайні книги, web-дизайні. На підставі стилістичного аналізу емпіричних матеріалів різних країн доведено, що стилістика школи «Баухауз» має художню та функціональну цінності, а її твори набули статусу світової мистецької спадщини.

Висновки. Проведене дослідження дозволило дійти висновків про те, що поряд із постмодерністськими та пост-постмодерністськими тенденціями продовжують жити фрундаментальні основи і принципи композиційного формоутворення Баухаузу. На початку XXI ст. в умовах стильового хаосу у різновидах дизайну та реклами доволі популярні функціоналізм, конструктивізм, мінімалізм, іноді сполучаючись з елементами інших стилів, утворюючи сучасний полістилізм. Аналізуючи складові худож- 
ньо-проектної культури, особливу увагу звертаючи на її естетичні проблеми, підкреслимо, по-перше, Баухауз вагомо вплинув на дизайн та рекламу в контексті візуальних комунікацій, по-друге, фрормоутворення дизайн-об'єктів детерміновано орієнтацієй на цільові групи з урахуванням певних функцій та естетичних ідеалів. Процеси глобалізації і деглобалізації спричинили суперечливі ситуації в культурно-мистецькому середовищі, для якого характерні не тільки диффрузні збагачення, еклектика, кітч, псевдонаціоналізація, а також повернення до «світу чистих фрорм» Баухаузу - площинності, геометрії, кольорографіки, активного пошуку їхніх новітних смислів. У найближчий перспективі необхідно невідкладно примножувати можливості для обміну і поширення важливого досвіду функціоналізму, щоб вирішити культурні, суспільні, економічні, технологічні, фрормотворчі та промислові зрушення майбутнього шляхом міждисциплінарних досліджень і дизайн-освіти.

\section{תimepamypa}

1. Баухаус - утопия, которая состоялась. URL: https://artchive.ru/encyclopedia/781 Baukhauz _utopija_kotoraja_sostojalas (дата зверн.: жовт. 2019).

2. Лаврентьев А. Родченко и Баухаус. В кн.: Ракурсы Родченко. Москва: Искусство, 1992. 224 с.

3. Прищенко С. Художньо-образна система рекламної графіки: монографія. Київ: НАКККіМ, 2018. 512 с.

4. Фиелл Ш., Фиелл П. Баухаус. В кн.: Энциклопедия дизайна (Концепции. Материалы. Стили). Москва: АСТ Астрель, 2008. 192 с.

5. Чепелик О. «Ікона модернізму» - 80-та річниця спорудження Баухаузу в Дессау // Сучасні проблеми дослідження, реставрації та збереження культурної спадщини. Київ: Інст. проблем сучасного мистецтва НАМ України, 2007. Вип.4. С. 371-385.

6. Akker R., Vermeulen T. Notes on Metamodernism // Journal of Aesthetics and Culture. 2010. Vol. 2. P. 114.

7. Bauhaus. Typography. Bonn: Verlag Bild-Kunst, 2017. $142 \mathrm{p}$.

8. Bayer H. Bauhaus. New York: Museum of Modern Art, 1972. 224 p.

9. Bergdoll B. Bauhaus 1919-1933. New York: Museum of Modern Art, 2009. 328 p.

10. Byars M. Design Encyclopedia. New York: J.Willey and Sons, 1994. 612 p.

11. Design is History. URL: www.designishistory.com (дата зверн.: жовт. 2019).

12. Droste M. Bauhaus. 1919-1933. London: Taschen, 2006. 256 p.

13. Friedewald B. Bauhaus. Munich-London-New York: Prestel, 2016. 128 p.

14. Graphic Design in Germany 1890-1945. Weimar and Now: German Cultural Criticism. University of California Press, 2000. 240 p.

15. Heller S. Graphic Style: From Victorian to Digital. New York: Harry N.Adams, 2001. 263 p.

16. Livingston A. Bauhaus. In book: The Dictionary of Graphic Design and Designers. New York: Thames and Hudson, 2003. 240 p.

17. Meggs P. History of Graphic Design. New York: John Wiley and Sons, 2006. 511 p.

18. Neef S. An Bord der Bauhaus. Zur Heimatlosigkeit der Moderne. Bauhaus-Universität Weimar. 2009. 240

s. 2005. $192 p$

19. Original Bauhaus - die 100 Jubiläumsausstellung in der Berlinischen Galerie // Weltkunst. Herbst 2019.

20. Pevsner N. Pioneers of Modern Design: From William Morris to Walter Gropius. Yale University Press,

21. Shop Window Exhibitions. URL: www.bauhaus100.berlin (дата зверн.: верес. 2019).

\section{References}

1. The Bauhaus is a utopia that has taken place. URL: https://artchive.ru/encyclopedia/781 Baukhauz utopija_kotoraja_sostojalas [in Russian].

2. Lavrent'ev, A. (1992). Rodchenko and Bauhaus. In.: Rodchenko angles. Moscow: Iskusstvo [in Russian].

3. Pryshchenko, S. (2018). Artistic-image system of advertising graphics: monograph. Kyiv: NAKKKiM [in Ukrainian].

4. Fiell, Sh., \& Fiell, P. (2008). Bauhaus. In.: Encyclopedia of Design (Concept. Materials. Styles). Moscow: AST Astrel [in Russian].

5. Chepelik, O. (2007). «Modernism icon» - 80th Anniversary of the Bauhaus Building in Dessau. Contemporary problems of research, restoration and preservation of cultural heritage. Kyiv: Inst. problem suchasnogo mistectva NAM Ukrayini. Issue 4. pp. 371-385 [in Ukrainian].

6. Akker, R., Vermeulen, T. (2010). Notes on Metamodernism. Journal of Aesthetics and Culture. Vol.2. pp. 1-14. [in English].

7. Bauhaus. Typography. (2017). Bonn: Verlag Bild-Kunst. [in English].

8. Bayer, H. (1972). Bauhaus. New York: Museum of Modern Art. [in English].

9. Bergdoll, B. (2009). Bauhaus 1919-1933. New York: Museum of Modern Art. [in English].

10. Byars, M. (1994). Design Encyclopedia. New York: J.Willey and Sons. [in English].

11. Design is History. URL: www.designishistory.com. [in English].

12. Droste, M. (2006). Bauhaus. 1919-1933. London: Taschen. [in English].

13. Friedewald, B. (2016). Bauhaus. Munich-London-New York: Prestel. [in English].

14. Graphic Design in Germany 1890-1945. Weimar and Now: German Cultural Criticism. (2000). University of California Press. [in English].

15. Heller, S. (2001). Graphic Style: From Victorian to Digital. New York: Harry N.Adams. [in English].

16. Livingston, A. (2003). Bauhaus. In book: The Dictionary of Graphic Design and Designers. New York: Thames and Hudson. [in English]. 